\title{
Isolation and identification of a new strain of hirame rhabdovirus (HIRRV) from Japanese flounder Paralichthys olivaceus in China
}

\author{
Jialin Zhang ${ }^{1}$, Xiaoqian Tang ${ }^{1 *}$, Xiuzhen Sheng ${ }^{1}$, Jing Xing ${ }^{1}$ and Wenbin Zhan ${ }^{1,2}$
}

\begin{abstract}
Background: Hirame rhabdovirus virus (HIRRV) is a rhabdovirus that causes acute hemorrhage disease in fish culture, resulting in a great economic loss in parts of Asia and Europe.

Methods: In this study, we isolated a virus strain named as CNPo2015 from cultured Japanese flounder in Shandong province, China. Cell isolation, electron microscopic observation, RT-PCR detection and phylogenetic analysis were used for virus identification. Further, artificial infection experiment was conducted for virulence testing.

Results: The gross signs included abdominal distension, fin reddening and yellow ascitic fluid in the abdominal cavity. Histopathological examination revealed marked cell degeneration and necrosis in the kidney. The tissue homogenates induced obvious cytopathic effects in EPC, FHM and FG cell lines. Electron microscopic observation showed the virus had a bullet-like shape with a capsule membrane. RT-PCR and sequencing analysis revealed that CNPo2015 belonged to the HIRRV with high sequence identity to HIRRV isolates. Infection experiment confirmed that the HIRRV CNPO2015 strain was virulent to flounder juveniles with a $L D_{50}$ value of $1.0 \times 10^{5.9} \mathrm{TCID}_{50} /$ fish.

Conclusion: In conclusion, we described the first isolation and characterization of a HIRRV from Japanese flounder in China. This will provide a candidate material for further research on the infection mechanism and preventive strategies of HIRRV.
\end{abstract}

Keywords: Hirame rhabdovirus, Paralichthys olivaceus, Identification, Pathogenicity

\section{Background}

Hirame rhabdovirus (HIRRV) is a single-stranded RNA virus, which belongs to the genus Novirhabdovirus within the family Rhabdoviridae. The virus was first described in cultured Japanese flounder in Japan in the early 1980s [1], from where it gradually spread to South Korea and China [2, 3]. However, due to increasing travels and rapid globalization, the outbreak of HIRRV has also been reported in part of Europe [4]. HIRRV can affect a wide range of marine fishes including Japanese

\footnotetext{
* Correspondence: tangxq@ouc.edu.cn

'Laboratory of Pathology and Immunology of Aquatic Animals, Ocean University of China, No.5 Yushan Road, Qingdao 266003, China

Full list of author information is available at the end of the article
}

flounder, stone flounder (Kareius bicoloratus), black seabream (Acanthopagrus schlegeli) and sea bass (Lateolabrax maculatus) [5]. The major clinical signs of HIRRV infection are congestion of the gonads, focal haemorrhage of the skeletal muscle and fins and accumulation of ascitic fluid [1]. Nowadays, the lack of vaccines and drugs against HIRRV highlights the urgency and significance of investigating infection mechanism and preventive strategies against HIRRV [6].

As with all novirhabdoviruses, the HIRRV genome encodes six viral proteins including nucleoprotein $(\mathrm{N})$, phosphoprotein $(\mathrm{P})$, matrix protein $(\mathrm{M})$, glycoprotein (G), non-structural (NV) and RNA polymerase protein (L) [7]. Among them, the G gene is relatively well conserved and often used as the target for HIRRV detection 
[8]. Sun et al. has established a reverse transcription PCR based on the G gene, which could specifically detect the HIRRV from other viruses [9]. The G protein also contains antigenic determinants that can induce antibodies in fish [10]. The DNA vaccine containing $G$ gene could induce protective immunity against HIRRV infection [11]. In addition, the $\mathrm{P}$ gene was usually employed for the phylogenetic and epidemiological studies [12]. As aforementioned, we chose the $\mathrm{P}$ gene as the target for phylogenetic analysis.

In the spring of 2015, a hemorrhage disease was observed in farmed Japanese flounder in Shandong province, China. Typical clinical signs exhibited by the diseased fish were congestion of the fins and accumulation of ascitic fluid. In the present study, we described the histopathological examination, cell culture isolation, electron microscopy, molecular confirmation and phylogenetic analysis. We further performed the artificial infection experiment to determine the virulence of the HIRRV CNPo2015 isolate.

\section{Methods}

\section{Sample collection}

In this study, diseased flounder juveniles (average weight of $30 \mathrm{~g}$, average body length of $15 \mathrm{~cm}$ ) come from a fish farm in Shandong province, China. The fish suffering from a hemorrhage disease were kept at a temperature ranged from 8 to $10{ }^{\circ} \mathrm{C}$, and the cumulative mortality rate was approximately $20 \%$ in a month. Five diseased fish and five healthy fish were taken for parasitological, bacteriological and virological examinations. The gills and mucus scrapings from the skin were inspected for the presence of parasites. The kidneys and spleens were homogenized and subjected to bacteria culture on brain-heart infusion agar plates at $15{ }^{\circ} \mathrm{C}$ for 7 days. Histopathological examinations were carried out using the tissue sections.

\section{Virus isolation}

The kidney, spleen, brain and gill tissues from five diseased fish were individually homogenized at a ratio of 1:10 (w/v) in M199 medium supplemented with 10\% FBS, and 1\% Penicillin-Streptomycin (Gibco). The tissue homogenates were filtered through a $0.22 \mu \mathrm{m}$ filter membrane and were inoculated on four fish cell lines including EPC, FHM, FG and CAR cell lines, cultured in M199 medium supplemented with 4\% FBS and 1\% Penicillin-Streptomycin at $15{ }^{\circ} \mathrm{C}$. The inoculated cell cultures were incubated at $15{ }^{\circ} \mathrm{C}$ for 7 days and examined daily for the presence of CPE. The cultures were centrifuged at $1,500 \times \mathrm{g}$ at $4{ }^{\circ} \mathrm{C}$ for $20 \mathrm{~min}$ and the supernatants were immediately stored at $-80{ }^{\circ} \mathrm{C}$. The obtained virus was named CNPo2015.

\section{Virus titering}

Three fish cell lines (EPC, FHM and FG) were used for virus titering. Prior to infection, the cells were transferred into 96-well plates and grew to monolayer cells. Serial 10 -fold dilutions of the tissue homogenate were inoculated on three fish cell lines. The cultures were maintained in M199 medium supplemented with $4 \% \mathrm{FBS}$ and $1 \%$ Penicillin-Streptomycin at $15{ }^{\circ} \mathrm{C}$. The virus titers on the cell lines were determined by $50 \%$ endpoint dilution assays $\left(\mathrm{TCID}_{50}\right)$ according to the method described by Reed and Muench [13].

\section{Electron microscopy}

EPC cell monolayers were incubated with the virus culture at a MOI of 0.1 for 2 days. Then the cultures were collected and fixed in $2.5 \%$ glutaraldehyde in phosphate buffer overnight. Ultrathin sections were prepared as previously described [14]. The sections were placed on grids and examined under a Jeol JEM-1200 EX electron microscope.

\section{RT-PCR and sequencing}

$500 \mu \mathrm{L}$ of culture supernatants was used for RNA extraction using TRIzol (Takara). The quality and quantity of RNA were checked using a NanoDrop ND-8000 spectrophotometer (Thermo Scientific). cDNA was synthesized from $1 \mu \mathrm{g}$ of RNA using M-MLV kit (Takara), according to the manufacturer's instructions. The resulting CDNA was used for PCR analyses of HIRRV, VHSV, IHNV, VNNV. The PCR was performed in a total volume of $25 \mu \mathrm{L}$ containing $1 \mu \mathrm{L}$ of cDNA, $2.5 \mathrm{U}$ of Taq DNA polymerase (Takara), $5 \mu \mathrm{L}$ of PCR reaction buffer, $0.5 \mu \mathrm{L}$ of each primer $(10 \mathrm{pmol})$ and RNase-free water. Normal EPC cell sample was used as the negative control. All the PCR amplifications were performed according to previous studies [9, 15-18], and the primer sets and PCR conditions were shown in Table 1. The products were examined by electrophoresis using a 1.0\% agarose gel. Then the products were sequenced using the BigDye ${ }^{\circ}$ v3.1 dye terminator and were analyzed on an ABI PRISM 3730 XL DNA Analyzer (Applied Biosystems, USA), following the manufacturer instruction. The obtained sequences were submitted in the NCBI website and blasted for similar sequences in the GenBank database.

\section{Phylogenetic analysis}

The ORF of the $\mathrm{P}$ gene was amplified for phylogenetic analysis. A pair of specific PCR primers (P-F: 5'ATGTCTGATAACGAAGGAG-3' and P-R: 5'CTACCTCATGGTCTTCTTG-3') were designed using Primer premier 5.0. The amplification was performed as follows: $94{ }^{\circ} \mathrm{C}$ for $5 \mathrm{~min}$, followed by 30 cycles of denaturing at $94{ }^{\circ} \mathrm{C}$ for $1 \mathrm{~min}$, annealing 
Table 1 Primers for specific detection of five different viruses

\begin{tabular}{|c|c|c|c|}
\hline Virus & Primers sequence & PCR condition ${ }^{a}$ & Source \\
\hline \multirow[t]{2}{*}{ HIRRV } & F: 5'-GTGCCAATGGTACACGGACAA-3' & $55^{\circ} \mathrm{C} / 35$ & [9] \\
\hline & R: 5'-TGATCTCCGCATGTGCCTCTA-3' & & \\
\hline \multirow[t]{2}{*}{ VHSV } & F:5'- ATGGAAGGAGGAATTCGTGAAGCG-3' & $55^{\circ} \mathrm{C} / 35$ & [15] \\
\hline & R:5'-GCGGTGAAGTGCTGCAGTTCC-3' & & \\
\hline \multirow[t]{2}{*}{ IHNV } & F: 5'-AGAGATCCCTACACCAGAGAC-3' & $50^{\circ} \mathrm{C} / 30$ & [16] \\
\hline & R: 5'-GGTGGTGTTGTTTCCGTGCAA-3 & & \\
\hline \multirow[t]{2}{*}{ VNNV } & F: 5'-CGTGTCAGTCATGTGTCGCT-3' & $55^{\circ} \mathrm{C} / 25$ & [17] \\
\hline & R: 5'-CGAGTCAACACGGGTGAAGA-3' & & \\
\hline \multirow[t]{2}{*}{ LCDV } & F: 5'-GCTGCTGATTTCGAATATGG-3' & $50^{\circ} \mathrm{C} / 30$ & [18] \\
\hline & R: 5'-GCTTGCATAGGCTTCTTC-3' & & \\
\hline
\end{tabular}

aPCR condition: annealing temperature/cycles

at $53{ }^{\circ} \mathrm{C}$ for $1 \mathrm{~min}$, extension at $72{ }^{\circ} \mathrm{C}$ for $1 \mathrm{~min}$ and finally incubation at $72{ }^{\circ} \mathrm{C}$ for $10 \mathrm{~min}$. The obtained PCR products were sequenced as described above, and the sequence was submitted to the GenBank database. The $\mathrm{P}$ gene sequence of CNPo2015 was compared with five other HIRRV isolates in GenBank. The sequences were aligned using Clustal software (version 1.81). Phylogenetic tree based on the $\mathrm{P}$ gene was constructed by MCMC method using the BEAST software (version 2.4.5) as previously described [19], and the phylogenetic tree was visualized using FigTree (version 1.4.3).

\section{Experimental infection}

Healthy flounder juveniles $(10 \sim 15 \mathrm{~cm}$, about $30 \mathrm{~g})$ were obtained from a farm in Rizhao, Shandong, China. Prior to the experiment, PCR assay was performed to confirm the fish free of HIRRV. All fish were held in seawater at a temperature of $10^{\circ} \mathrm{C}$. After acclimation for 7 days, a total of 150 fish were randomly divided into five groups (30 fish per group). Fish in each group were injected intraperitoneally with $100 \mu \mathrm{L}$ of virus culture $\left(10^{7.5}, 10^{6.5}, 10^{5.5}, 10^{4.5} \mathrm{TCID}_{50}\right.$ per fish). In addition, fish in the control group were injected with equivalent amount of M199 media. All fish were checked daily for clinical signs and mortalities for 14 days.

\section{Results}

\section{Gross examination and histopathology}

The external clinical signs observed in the diseased fish were skin darkening, abdominal distension, fin reddening (Fig. 1a). After dissection, diseased fish showed visceral pallor, capillaries expansion and yellow ascitic fluid in the abdominal cavity (Fig. 1b). No bacteria or parasites were isolated from the fish samples. Histological examination showed that most of the kidney cells were characterized by marked cell degeneration and necrosis. The formation of broken nucleus and pathologic pigmentation were also present in kidneys (Fig. 1d).

\section{Virus isolation and titration}

The homogenate supernatants of kidney and spleen tissues induced positive CPE in the EPC, FHM, FG cells at 3 days post inoculation at $15{ }^{\circ} \mathrm{C}$. The $\mathrm{CPE}$ was characterized by rounded and granular cells, grape-like clusters, cell detached and lysis. No CPE was observed in the CAR cell line (Fig. 2). In all cell lines, no CPE was induced by the brain and gill samples. At 7 days post inoculation, the EPC cells produced the highest titer of virus with a titer of $1 \times 10^{8.5} \mathrm{TCID}_{50} / \mathrm{mL}$, while the titer was $1 \times 10^{8.1} \mathrm{TCID}_{50} / \mathrm{mL}$ for FHM cells, and $1 \times 10^{7.3}$ $\mathrm{TCID}_{50} / \mathrm{mL}$ for FG cells, respectively. Virus titers in all cell lines stabilized for the remainder of the infection.

\section{Electron microscopic observation}

Transmission electron microscopy showed that abundant viral particles were aggregated on the surface of cells at 2 days post inoculation (Fig. 3a). Meanwhile, some particles were also found inside the cytoplasm with a vesicle encapsulated (Fig. 3b). The intact virion exhibited a bullet-shaped capsid enclosed with envelope. Moreover, the virion averaged approximately $160 \mathrm{~nm}$ in length and $80 \mathrm{~nm}$ in width.

\section{RT-PCR detection}

As shown in Fig. 4, a specific band was amplified from virus culture supernatants using HIRRV specific primers, while no product was detected in the normal EPC cell samples (data not shown). No product was detected using primers of VHSV, IHNV, VNNV or LCDV. The G gene fragment of CNPo2015 revealed 100\% sequence identity with the known HIRRV isolates.

\section{Phylogenetic analysis of the P gene}

The P gene of CNPo2015 strain was amplified and the complete ORF sequence was submitted to GenBank under accession number KY701726. The $\mathrm{P}$ gene sequence analysis showed CNPo2015 had the highest nucleotide sequence identity to 080113 strain and SSB13 

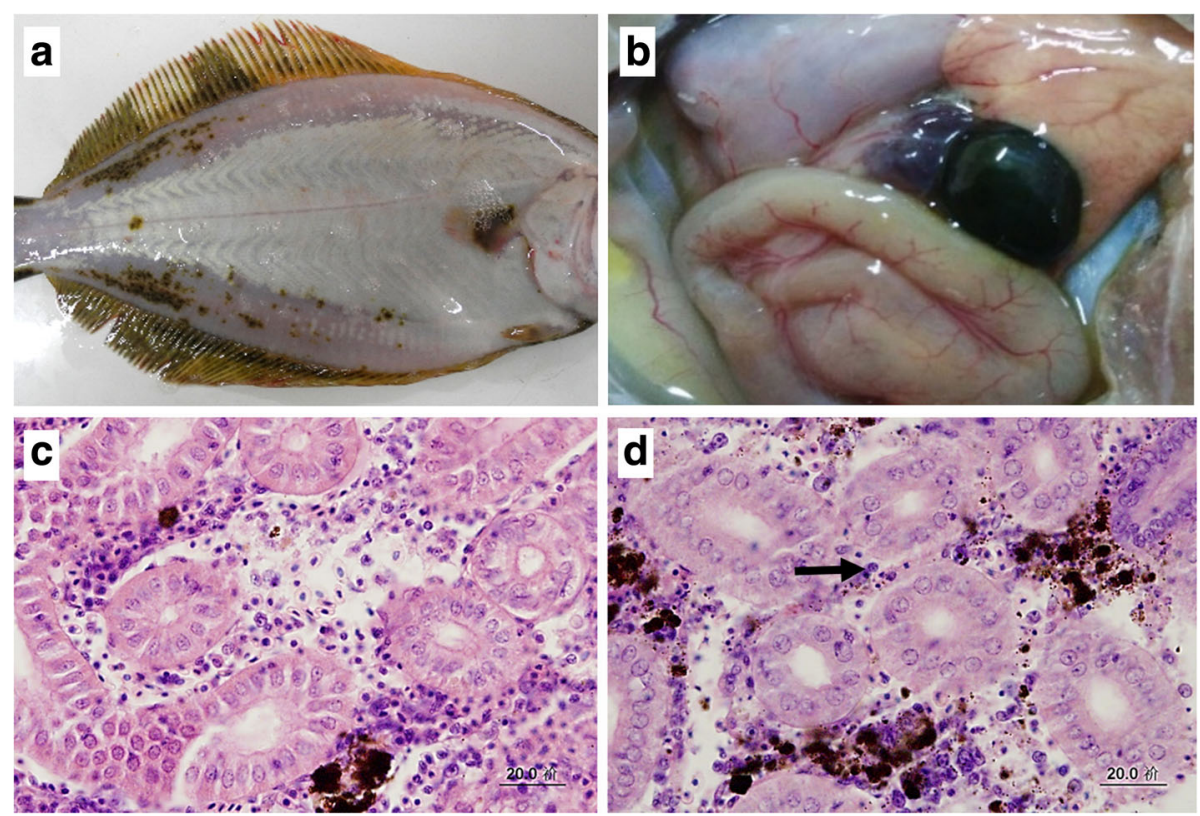

Fig. 1 Clinical signs and pathologic changes of diseased Paralichthys olivaceus. a Symptoms on the surface of diseased fish showed congested fins, expanded abdomen and dark body color. b Gross appearance of visceral of diseased fish displayed signs including dark red spleen, congested intestine, and yellow ascitic fluid. c Kidney section of healthy fish. $\mathbf{d}$ Kidney section of diseased fish displayed pathologic changes including cell degeneration and necrosis (arrow), karyopyknosis with pieces of broken nucleus. Scale bars $=20 \mu \mathrm{m}$

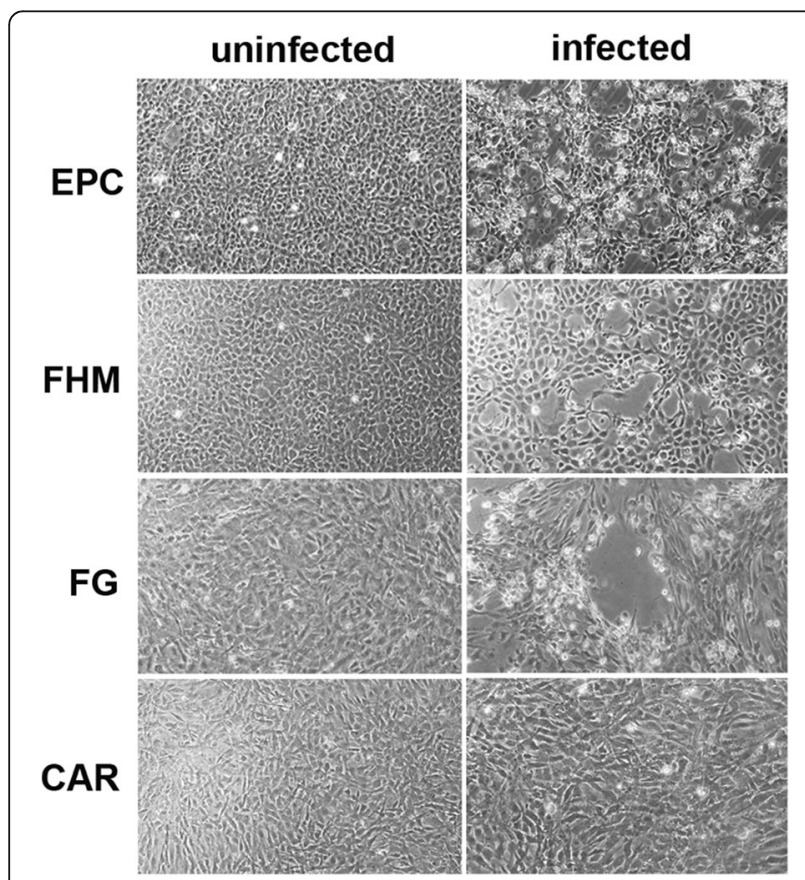

Fig. 2 Virus isolation on four fish cell lines. Compared with uninfected fish cell lines, the infected EPC cell line showed typical CPE with cell rounding, detachment and dead cells. The infected FHM and FG cell lines were also observed with CPE. No CPE were observed in CAR cell line. Magnification, $30 \times$

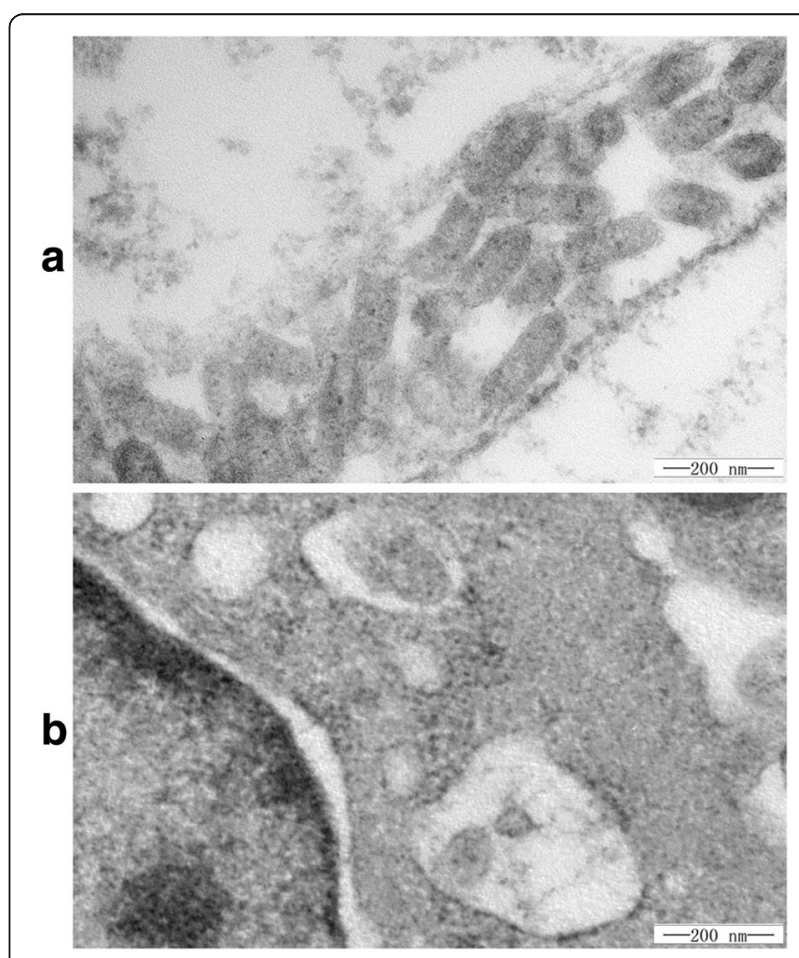

Fig. 3 Morphology of the virions under electron microscope. a A large amount of virions aggregated on the surface of the cell. b Virions were wrapped by vesicles in the cytoplasm. Scale bars $=200 \mathrm{~nm}$ 


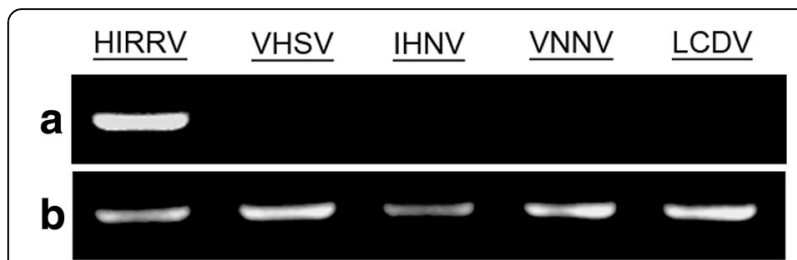

Fig. 4 RT-PCR analysis. a RT-PCR amplification from infected EPC cells using specific primers of HIRRV, VHSV, IHNV, VNNV and LCDV. $\mathbf{b}$ The flounder $\beta$-actin was used as an internal control gene

strain (98.5\%), followed by CA-9703 strain and 8401-H strain (98.1\%) and Kor-TY15 strain (97.4\%). A phylogenetic tree based on the $\mathrm{P}$ gene ORF sequences revealed that CNPo2015 strain was clustered in a clade with 8401-H strain and CA-9703 strain. It showed that CNPo2015 strain was farther to SSB13 strain, 080113 strain and Kor-TY15 strain, which were isolated from spotted sea bass, stone flounder and black seabream, respectively (Fig. 5).

\section{Experimental infection}

Flounder juveniles were inoculated with different doses of the HIRRV CNPo2015 strain. Symptoms such as abdominal distension and fin reddening appeared on day 4 and began to die on day 5 post-infection. At 14 days post-infection, fish infected with $10^{7.5}, 10^{6.5}, 10^{5.5}, 10^{4.5}$ TCID $_{50}$ of CNPo2015 strain had cumulative mortalities of $100,60,40$ and $10 \%$, respectively (Fig. 6). Mortality rates in each group were plotted and the $\mathrm{LD}_{50}$ in juvenile flounder was determined to be $1.0 \times 10^{5.9} \mathrm{TCID}_{50} /$ fish. No signs or mortalities were observed in the control fish during the experiment.

\section{Discussion}

In China, the first HIRRV isolation was reported in cultured stone flounder in 2010 [3]. Although there were some cases discovered with similar symptoms in other marine fish, no formal reports on the virus identification have been reported. In 2015, a virus strain CNPo2015 was isolated from diseased Japanese flounder in Shandong Province, China. It caused severe symptoms such as visceral congestion and ascitic fluid in diseased fish, which were in accordance with the HIRRV infection cases [20]. Therefore, this study described a comprehensive understanding of the pathology of CNPo2015 with virus isolation, electron microscopy analysis, molecular comparison and virulence analysis. The results suggested that the CNPo2015 strain belonged to HIRRV.

HIRRV infection could cause severe disease with high morbidity and mortality in susceptible fish [21]. However, there are some factors that can influence the pathogenicity of rhabdovirus. It has been reported that water temperature plays important roles in the onsets and development of diseases [22]. High mortality of HIRRVinfected fish often occurred when water temperatures decreased under $15{ }^{\circ} \mathrm{C}$, while the symptoms relieved when the water temperature rose above $15{ }^{\circ} \mathrm{C}$ [23]. In our study, a high mortality rate in juvenile flounders occurred when the temperature was about $10{ }^{\circ} \mathrm{C}$. Additionally, the host age is also an important influence factor. Previous studies showed that adult flounders $(100 \sim$ $250 \mathrm{~g}$ ) and fry flounders (about $10 \mathrm{~g}$ ) injected with $10^{6}$ TCID $_{50}$ of HIRRV showed cumulative mortalities of 25 and $100 \%[1,24]$. In our study, we calculated a cumulative mortality of $60 \%$ in juvenile flounders (about $30 \mathrm{~g}$ ) injected with the same dose of HIRRV. Therefore, age and water temperature can be considered the important factors for making preventive strategies of HIRRV.

Phylogenetic analysis confirmed that the $\mathrm{P}$ gene sequence of the CNPo2015 strain was similar with other HIRRV isolates (more than 97\% sequence identity), which was consistent with a previous report [25]. Among the different HIRRV isolates, the CNPo2015

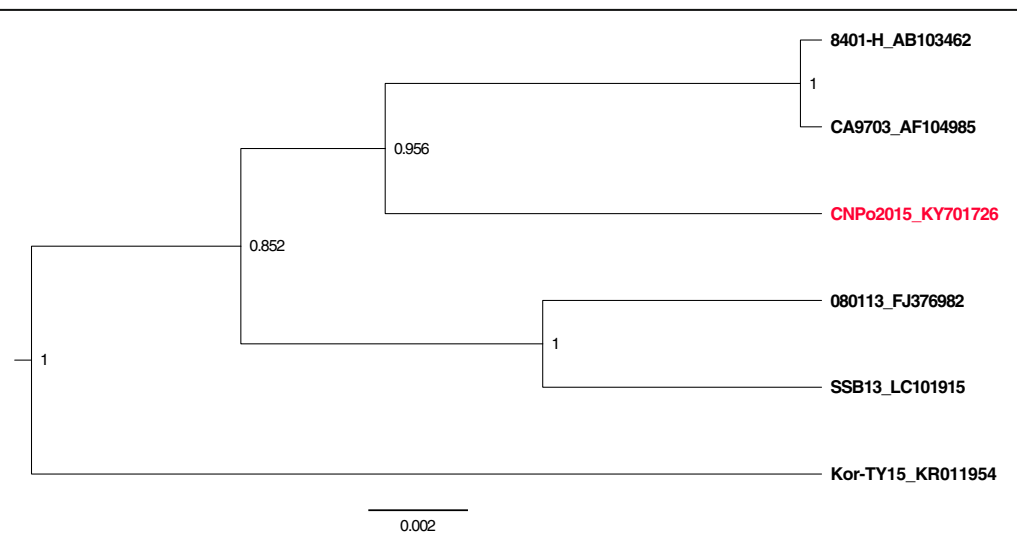

Fig. 5 Phylogenetic analysis performed using P genes from six HIRRV isolates. The P gene sequence of the HIRRV CNPo2015 is in red color. The scale bar at the bottom indicates 0.002 nucleotide substitutions per site 


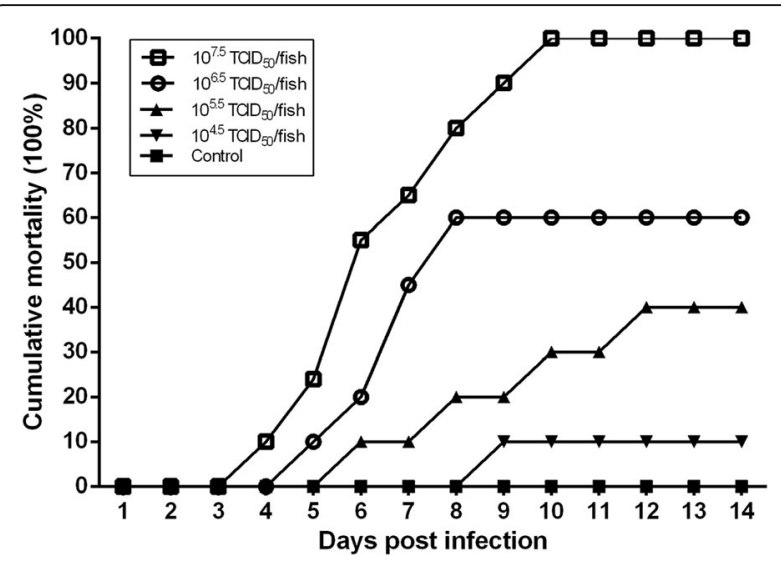

Fig. 6 Cumulative mortality rates of flounder juveniles after challenge with different doses of the HIRRV CNPo2015 through day 14 post-infection. Each group contained 30 fish

strain was more closely related to the HIRRV strains 8401-H and CA-9703, which were previously isolated from Japanese flounder in Japan and Korea, respectively. This is probably as a result of increasing global trade and introduction breeding that accelerate the virus transmission. Nevertheless, it was noted that all the known isolates of HIRRV shared a high sequence identity, which could be speculated that all the isolates may originate from a same population. Therefore, a complete genome sequence analysis might be needed for further assessment of the genetic relationship among the different HIRRV isolates.

\section{Conclusions}

In conclusion, we described the isolation and characterization of a HIRRV isolate from Japanese flounder in China. The present isolate was closely related to known HIRRV isolates. It could infect diverse fish cell lines and induce obvious CPE. Result from the infection experiment revealed that CNPo2015 strain was virulent to juvenile flounder. Further studies will be focused on the infection mechanism and preventive strategies of HIRRV.

\section{Abbreviations}

CAR: Carp fin; CPE: Cytopathic effects; EPC: Epithelioma papulosum cyprini; FBS: Fetal bovine serum; FG: Flounder gill; FHM: Fathead minnow; IHNV: Infectious hematopoietic necrosis virus; LCDV: Lymphocystis disease virus; LD 50 : Median lethal dose; MCMC: Markov chain Monte Carlo; MOI: Multiplicity of infection; ORF: Open reading frame; SVCV: Spring viremia of carp virus; $\mathrm{TCID}_{50}$ : $50 \%$ tissue culture infective dose; VHSV: Viral hemorrhagic septicemia virus; VNNV: Viral nervous necrosis virus

\section{Acknowledgments}

Not applicable.

\section{Funding}

This study was supported by the National Natural Science Foundation of China (31672685; 31672684; 3142295), Taishan Scholar Program of Shandong
Province and the Open Foundation of Functional Laboratory for Marine Fisheries Science and Food Production Processes.

\section{Authors' contributions}

Zhan conceived and designed the study. Tang designed the experiments. Zhang performed the experiments. Sheng and Xing provided critique to the manuscript. Zhang and Tang contributed to data analysis and manuscript preparation. All authors have read and approved the manuscript.

\section{Competing interests}

The authors declare that they have no competing interests.

\section{Consent for publication}

Not applicable.

\section{Ethics approval}

This study was performed in strict accordance with the recommendations in the Guide for the Institutional Animal Care and Use Commission (IACUC). The protocols were approved by the Committee on the Ethics of Animal Experiments of the Ocean University of China. All experiments were performed under MS-222 anesthesia, and every effort was made to minimize suffering.

\section{Publisher's Note}

Springer Nature remains neutral with regard to jurisdictional claims in published maps and institutional affiliations.

\section{Author details}

${ }^{1}$ Laboratory of Pathology and Immunology of Aquatic Animals, Ocean University of China, No.5 Yushan Road, Qingdao 266003, China. 'Laboratory for Marine Fisheries Science and Food Production Processes, Qingdao National Laboratory for Marine Science and Technology, No.1 Wenhai Road, Qingdao 266071, China.

Received: 18 January 2017 Accepted: 29 March 2017

Published online: 07 April 2017

\section{References}

1. Kimura T, Yoshimizu M, Gorie S. A new rhabdovirus isolated in Japan from cultured hirame (Japanese flounder) Paralichthys olivaceus and ayu Plecoglossus altivelis. Dis Aquat Organ. 1986;1:209-17.

2. Oh MJ, Choi TJ. A new rhabdovirus (HRV-like) isolated in Korea from cultured Japanese flounder Paralichthys olivaceus. J Fish Pathol. 1998;11:129-36.

3. Yingjie S, Min Z, Hong L. Analysis and characterization of the complete genomic sequence of the Chinese strain of hirame rhabdovirus. J Fish Dis. 2011;34:167-71.

4. Borzym E, Matras M, Majpaluch J, Baud M. First isolation of hirame rhabdovirus from freshwater fish in Europe. J Fish Dis. 2014;37:423-30.

5. Seo H, Do JW, Jung SH. Outbreak of hirame rhabdovirus infection in cultured spotted sea bass Lateolabrax maculatus on the western coast of Korea. J Fish Dis. 2016:39:1239-46.

6. Takano T, Iwahori A, Hirono I. Development of a DNA vaccine against hirame rhabdovirus and analysis of the expression of immune-related genes after vaccination. Fish Shellfish Immunol. 2004;17:367-74.

7. Walker PJ, Dietzgen RG, Joubert DA. Rhabdovirus accessory genes. Virus Res. 2011;162:110-25.

8. Hill BJ. Physico-chemical and serological characterization of five rhabdoviruses infecting fish. J Gen Virol. 1975;27:369-78.

9. Sun YJ, Yue ZQ, Liu H, Zhao YR, Liang CZ, Li Y. Development and evaluation of a sensitive and quantitative assay for hirame rhabdovirus based on quantitative RT-PCR. J Virol Methods. 2010;169:391-6.

10. Joung IE, Myung JH, Sung JJ, Song YH, Tae JC. The protective effect of recombinant glycoprotein vaccine against HIRRV infection. Fish Pathol. 2001; 36:67-72.

11. Byon JY, Ohira T, Hirono I. Comparative immune responses in Japanese flounder, Paralichthys olivaceus after vaccination with viral hemorrhagic septicemia virus (VHSV) recombinant glycoprotein and DNA vaccine using a microarray analysis. Vaccine. 2006;24:921-30.

12. Kim DH, Oh HK, Eou Jl, et al. Complete nucleotide sequence of the hirame rhabdovirus, a pathogen of marine fish. Virus Res. 2005;107:1-9.

13. Reed $\amalg$, Muench $H$. A simple method of estimating fifty percent endpoints. Am J Epidemiol. 1938;27:493-7. 
14. Tang X, Li Z, Zhan W. Isolation and characterization of pathogenic Listonella anguillarum of diseased half-smooth tongue sole (Cynoglossus semilaevis günther). J Ocean U China. 2008;7:343-51.

15. Snow M, Bain N, Black J, Taupin V, Cunningham CO, King JA. Genetic population structure of marine viral haemorrhagic septicaemia virus (VHSV). Dis Aquat Organ. 2004;61:11-21.

16. Emmenegger EJ, Meyers TR, Burton TO, Kurath G. Genetic diversity and epidemiology of infectious hematopoietic necrosis virus in Alaska. Dis Aquat Organ. 2000;40:163-76.

17. Nishizawa T, Mori Kl, Nakai T, Furusawa I, Muroga K. Polymerase chain reaction (PCR) amplification of RNA striped jack nervous necrosis virus (SJNNV). Dis Aquat Organ. 1994;18:103-7.

18. Wu R, Tang X, Sheng X, Zhan W. Relationship between expression of cellular receptor-27.8 $\mathrm{kDa}$ and lymphocystis disease virus (LCDV) infection. PLoS One. 2015:10:e0127940.

19. Moura IF, Lopes EP, Alvarado-Mora MV, et al. Phylogenetic analysis and subgenotypic distribution of the hepatitis B virus in Recife, Brazil. Infect Genet Evol. 2013;14:195.

20. Kim WS, Oh MJ. Hirame rhabdovirus (HIRRV) as the cause of a natural disease outbreak in cultured black seabream (Acanthopagrus schlegeli) in Korea. Arch Virol. 2015;160:3063-6.

21. Yasuike $\mathrm{M}$, Kondo $\mathrm{H}$, Hirono I. Difference in Japanese flounder, Paralichthys olivaceus gene expression profile following hirame rhabdovirus (HIRRV) G and N protein DNA vaccination. Fish Shellfish Immunol. 2007:23:531-41.

22. Sano M, Ito T, Matsuyama T, Nakayasu C, Kurita J. Effect of water temperature shifting on mortality of Japanese flounder Paralichthys olivaceus experimentally infected with viral hemorrhagic septicemia virus. Aquaculture. 2009;286:254-8.

23. Oseko N, Yoshimizu M, Kimura T. Effect of water temperature on artificial infection of rhabdovirus olivaceus (hirame rhabdovirus: HRV) to hirame (Japanese flounder, paralichthys olivaceus). Fish Pathol. 1988;23:125-32.

24. Ji Y, Kim KH, Kim SG, Oh MJ, Nam SW, Kim YT. Protection of flounder against hirame rhabdovirus (HIRRV) with a DNA vaccine containing the glycoprotein gene. Vaccine. 2006;24:1009-15.

25. Nishizawa T, Yoshimizu M, Winton J. Characterization of structural proteins of hirame rhabdovirus, HRV. Dis Aquat Organ. 1991;10:167-72.

\section{Submit your next manuscript to BioMed Central and we will help you at every step:}

- We accept pre-submission inquiries

- Our selector tool helps you to find the most relevant journal

- We provide round the clock customer support

- Convenient online submission

- Thorough peer review

- Inclusion in PubMed and all major indexing services

- Maximum visibility for your research

Submit your manuscript at www.biomedcentral.com/submit

) Biomed Central 